\title{
Articles
}

\section{Self-Government at the Court of Justice of the European Union: A Bedrock for Institutional Success}

\author{
Christoph Krenn
}

\begin{abstract}
This contribution deals with a topic that has so far received scant attention: the administrative governance of the Court of Justice of the European Union (CJEU). Over the course of the last 65 years, the CJEU has developed its own particular version of judicial self-government. This article analyzes its genesis, its characteristic features and provides a comprehensive assessment. Three arguments are put forward: First, self-government at the CJEU can be associated with a number of positive effects for the Court as an institution. It contributes to keeping the Court out of the public limelight, to fostering its judicial authority vis-à-vis key compliance constituencies and to securing its judicial independence. Second, while strong forms of judicial self-government can lead to a lack of transparency and accountability, these problematic side effects have been largely avoided at the CJEU. This is, in many respects, due to the dialogic accountability relationship that has been established with the European Parliament in the context of the EU budgetary process. Nevertheless, third, as regards more recent developments, such as the establishment of an expert panel for selecting new CJEU members and the Court's legislative role in amending its own Statute, from the perspective of transparency, room for improvement exists.
\end{abstract}

\footnotetext{
- Senior Research Fellow at the Max Planck Institute for Comparative Public Law and International Law, Heidelberg. I am grateful for comments and critique to David Kosař, Hubert Smekal and Davide Paris. All mistakes are, of course, my own. Email: krenn@mpil.de.
} 


\section{A. Introduction: the CJEU's debt to international law}

When the Court of the European Coal and Steel Community, the predecessor of the Court of Justice of the European Union (CJEU), ${ }^{1}$ was established in 1952, it was considered innovative in many respects. Commentators of the time described it as a departure from the standard model of international adjudication. ${ }^{2}$ And yet, the Coal and Steel Court borrowed from classic international law one of the most enduring features of its institutional design: the basic idea of its internal governance structure. The Court has taken inspiration from the International Court of Justice (ICJ) and has, over the course of the last 65 years, developed its own particular version of judicial self-government (JSG). This article describes the development and characteristic features of JSG at the CJEU, explains how it relates to the Court's judicial authority, its independence, and the public confidence invested in the Court, and assesses it from the perspective of transparency and accountability. ${ }^{3}$ Such analysis has so far not been undertaken. Since the literature on the CJEU's administrative governance is generally scarce, ${ }^{4}$ and in order to paint a more vivid picture, this contribution will be partially based on unpublished CJEU administrative documents. $^{5}$

The article puts forward three arguments. First, the CJEU's particular version of JSG can be associated with positive effects for the Court as an institution. It contributes to keeping the Court out of the public limelight, to fostering its judicial authority vis-à-vis key compliance constituencies and to securing its independence. Put poignantly, it can be described as a bedrock for the Court's institutional success. Second, while strong JSG has, in many judicial

\footnotetext{
${ }^{1}$ The CJEU consists of two courts, the European Court of Justice (ECJ) and the General Court (GC).

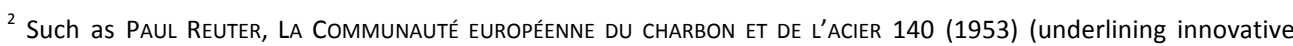
features from an international law perspective such as direct standing for undertakings); see also Hermann Mosler, Der Vertrag über die Europäische Gemeinschaft für Kohle und Stahl. Entstehung und Qualifizierung 14 ZEITSCHRIFT FÜR AUSLÄNDISCHES ÖFFENTLICHES RECHT UND VÖLKERRECHT 1, 42-43 (1951) (comparing the functions of the Coal and Steel Court to those of an administrative and constitutional tribunal).

${ }^{3}$ On the broader objectives of the special issue of which this contribution forms part, see, David Kosař, Beyond Judicial Councils: Forms, Rationales and Impact of Judicial Self-Governance in Europe, 19 GERMAN L.J. (2018).

${ }^{4}$ For overviews written by Court insiders see, Roger Grass, Les ressources humaines à la Cour de justice des Communautés européennes, in Le DROIT A LA MESURE DE L'HOMME. MELANGES EN L'HONNEUR DE PHILIPPE LEGER 69 (Yves Bot et al. eds., 2006); Roger Grass and Alfredo Calot Escobar, 2004-2014: Une période déterminante pour les ressources de l'institution, in LA COUR DE JUSTICE DE L'UNION EUROPEENNE SOUS LA PRESIDENCE DE VASSILIOS SKOURIS (20032015). LIBER AMICORUM VASSILIOS SKOURIS 227 (Antonio Tizzano et al eds., 2015); for contributions that exceptionally - take a more normative take on the issue, Marc van der Woude, Towards a European Council of the Judiciary: Some Reflections on the Administration of the EU Courts, in DEMOCRACY AND RULE OF LAW IN THE EUROPEAN UNION. ESSAYS IN HONOUR OF JAPP W. DE ZWAAN 63 (Flora A.N.J. Goudappel \& Ernst M. H. Hirsch Ballin eds., 2016); and Franklin Dehousse, The Reform of the EU Courts (II). Abandoning the Management Approach by Doubling the General Court, in 83 EGMONT PAPER (2016).
}

${ }^{5}$ Documents have been received through access to documents requests 0017/2015D and 0008/2018D. 
systems, important downsides from the perspective of transparency and accountability, ${ }^{6}$ these problems are attenuated at the CJEU. This is due to high standards of transparency that the EU Treaties set up for the Court when performing tasks of court administration but also, and even more importantly, due to the Court's constructive and dialogic relationship with the European Parliament. The CJEU's activities in the field of court administration are overseen by the Parliament in the course of the annual budgetary discharge procedure, where the Court is held to account for how it organizes the institution and where it receives input on how to improve. Nevertheless, third, as regards more recent developments, such as the establishment of an expert panel for selecting new CJEU members and the Court's legislative role in amending its own Statute, from the perspective of transparency, room for improvement exists.

The first part of this contribution traces the development of JSG at the CJEU and explains its central features. The second part investigates how the design of JSG at the CJEU can be seen to affect public confidence in the Court, its judicial authority and independence. The third and final part explains the mechanisms in place to ensure that - in governing the Court - the CJEU respects EU law standards of transparency and that it can be held accountable in case of mismanagement. Moreover, it points to a number of problematic features from the perspective of transparency.

\section{B. Collegial self-government: the genesis of the CJEU's governance model}

In discussing JSG at the CJEU, we will start at the very beginning, namely with the CJEU's predecessor, the Coal and Steel Court, established on 4 December 1952. Although today's CJEU bears little resemblance to the early European judiciary in terms of political power and institutional size, as regards JSG, important ideas stem from these early years (I.). In a second step, we will see how the Coal and Steel Court's model of JSG has been adapted and further developed over time (II.). First, by adjusting the concept of collegial selfgovernment for an institution that has dramatically grown from 9 judicial members and a staff of 65 people (1956) to an institution of 84 judicial members and a staff of 2174 (2018). Second, by tightening the regime for regulating CJEU members' conduct while in office. And third, by gently pushing JSG into a field that is traditionally out of bounds in the classic international law conception of judicial governance, namely the selection of new judges and Advocates General.

\footnotetext{
${ }^{6}$ See, Kosař, supra note 3.
} 


\section{The beginnings: JSG at the Coal and Steel Court}

The Coal and Steel Court was set up in 1952 as the judicial organ of the Coal and Steel Community, a community of six states. ${ }^{7}$ The Court's main task was to check on the powers of the High Authority, the predecessor of the European Commission. Since these were largely issues an administrative court would perform at the domestic level, the French Conseil d'État served as an important inspiration for the Coal and Steel Court's design. ${ }^{8}$ However, when it came to the Court's organizational structure, the drafters of the Statute looked elsewhere. As a French commentator of the time noted: 'The organization of the Coal and Steel Court is reminiscent, in its entirety, of the $\mathrm{ICJ}^{\prime{ }^{9}}$ This started with details, such as the gowns of the judges that were fashioned in the style of the ICJ. ${ }^{10}$ On a more fundamental level, the Coal and Steel Court borrowed important rules and ideas on judicial governance from the World Court. ${ }^{11}$

The first principle borrowed was that of self-governance. ${ }^{12}$ The organization of the Coal and Steel Court was assigned to the first generation of judges and Advocates General. The Court members themselves built the Court's administration. They each hired a legal assistant of their nationality and were assigned a secretary. ${ }^{13}$ Moreover, the Luxembourg judge Charles Léon Hammes, being acquainted with the customs of the Court's hosting state, oversaw the recruitment of the Court's first administrative staff. ${ }^{14}$ In 1956, when all

\footnotetext{
${ }^{7}$ Belgium, France, Germany, Italy, Luxembourg and the Netherlands.

${ }^{8}$ The main procedural venue in the original setup of the Coal and Steel Court, the annulment procedure, reflects a strong imprint of French administrative law; see Thijmen Koopmans, The Birth of European Law at the CrossRoads of Legal Traditions, 39 AMERICAN JOURNAL OF COMPARATIVE LAW 493, 500 (1953).

9 Jean L'Huillier, Une conquête du droit administratif français: Le contentieux de la Communauté européenne du charbon et de l'acier, 13 RECUEIL DALLOZ: CHRONIQUE 63, 66 (1953) (my translation).

${ }^{10}$ Recounting this anecdote, Albert van Houtte, Souvenirs de la Cour de justice. 1953-1982, in XXXV ANNI. 19521987 69, 79 (Alexander Mackenzie Stuart ed., 1987).

${ }^{11}$ See, Anik Antoine, La Cour de Justice de la C.E.C.A. et la Cour internationale de Justice, 57 REVUE GENERALE DE DROIT INTERNATIONAL PUBLIC 210, 261 (1953); further, on inspiration drawn from the ICJ, see LOUIS DELVAUX, LA COUR DE JUSTICE DE LA COMMUNAUTE EUROPEENNE DU CHARBON ET DE L'ACIER. EXPOSE SOMMAIRE ET DES PRINCIPES 16 (1956).

12 On self-government in international courts as a rule of customary international law, see, Karin Oellers-Frahm, Der institutionelle Rahmen: Status, Ausstattung und Personalhoheit internationaler Gerichte. Der IGH, der Internationale Strafgerichtshof und das Jugoslawien-Tribunal im Vergleich, 30 EUROPÄISCHE GRUNDRECHTE ZEITSCHRIFT 107, 117 (2003).

${ }^{13}$ See, Otto Riese, Erfahrungen aus der Praxis des Gerichtshofs der Europäischen Gemeinschaft für Kohle und Stahl, DeutSChe RichteRzeitung 270, 271 (1958); for an interesting account of how Otto Riese, the first German judge at the Coal and Steel Court, selected his law clerk, see, Hans Wolfram Daig, Erinnerungen an die Frühzeit des Gerichtshofes, in XXXV ANNI. 1952-1987 127, 128 (Alexander Mackenzie Stuart ed., 1987).

${ }^{14}$ René Hochstrass, Les premiers jours de la Cour, in XXXV ANNI. 1952-1987 119, 119 (Alexander Mackenzie Stuart ed., 1987).
} 
positions had been filled, the administrative personnel counted 65 people: three librarians, eight translators, nine drivers, five court ushers, two accountants, and a number of typists. $^{15}$

The communal spirit of the early days translated into the Court's every-day practice. The Coal and Steel Court rested on a basic organizational structure that is, in principle, still in place at the CJEU today. All major decisions concerning its administration were assigned to a central self-government body, the réunion générale, which comprised the Coal and Steel Court's seven judges. ${ }^{16}$ They were joined by the two Advocates General in an advisory capacity and the Court's Registrar assisted the meetings. ${ }^{17}$ The réunion générale had a vast set of competences. In the field of appointing and managing personnel, it selected the Court's Registrar, ${ }^{18}$ all of the Court's administrative staff ${ }^{19}$ and the law clerks; ${ }^{20}$ and defined their duties and status. ${ }^{21}$ The réunion générale was also competent for disciplinary matters, could lift the immunity of a judge, ${ }^{22}$ force judges to recuse themselves in specific cases, ${ }^{23}$ but also deprive a judge of office by unanimous vote if he or she no longer fulfilled the requisite conditions for office. ${ }^{24}$ As regards these latter rules, the respective provisions were literally copied from the ICJ Statute. ${ }^{25}$

\footnotetext{
${ }^{15}$ A complete list can be found in the report of the Coal and Steel Community's auditor, RAPPORT DU COMMISSAIRE aux COMPTES URBain J. VAes Relative AU QUATRIEME EXERCiCe FinANCIER 20 (deuxième volume, 1 juillet 1955 au 30 juin 1956).

${ }^{16}$ To be sure, the role of international courts' plenaries in administrative and disciplinary matters differs between courts, see Stéphanie Cartier and Cristina Hoss, The Role of Registries and Legal Secretariats in International Judicial Institutions, in THE OXFORD HANDBOOK OF INTERNATIONAL ADJUDICATION 711, 717 (Cesare Romano, Karen Alter \& Yuval Shany eds., 2014).

${ }^{17}$ Only if administrative questions directly concerned the office of Advocate General, the Court decided upon their proposal; see Article 25 para 7 Coal and Steel Court Rules of Procedure (RoP).

${ }^{18}$ Article 14 Coal and Steel Court Statute.

${ }^{19}$ Article 12 para 1 Coal and Steel Court RoP.

${ }^{20}$ Article 20 Coal and Steel Court RoP.

${ }^{21}$ Article 14 and 16 Coal and Steel Court Statute.

${ }^{22}$ Article 3 Coal and Steel Court Statute.

${ }^{23}$ Article 19 Coal and Steel Court Statute (in case the need was seen for a judge to recuse himself, he could be informed by the President of the Court. In case of conflict, the plenary would decide).

${ }^{24}$ On the grounds for disciplinary proceedings see, JEAN DE RICHEMONT, LA COUR DE JUSTICE. CODE ANNOTÉ. GUIDE PRATIQUE 15-16 (1954); for Advocates General a different rule applied, they could be deprived of office through unanimous Council decision; see Article 13 para 2 Coal and Steel Court Statute; further, KPE LASOK, THE EUROPEAN Court of Justice. Practice And Procedure 19 (2nd ed., 1994).

${ }^{25}$ Antoine, supra note 11, at 261.
} 
The only field of judicial government that was strictly out of bounds for the Coal and Steel Court was the recruitment of new judicial members. While the judges and Advocates General were free to organize the institution at their will, when it came to selecting new judicial members, the Member States kept a tight grip on the Court. Also, this was in line with international law practice at the time. ${ }^{26}$ According to Article 32 of the European Coal and Steel Treaty, judges were selected by 'common accord' of the Member States for a renewable term of six years. In practice, individual governments nominated their candidates who were then rubber-stamped by the other Member States. ${ }^{27}$

\section{Continuity and change: the central features of JSG today}

The European integration project has significantly evolved since the 1950s and so has the European Court. In 1958, the Coal and Steel Court was merged with the newly established Court of Justice of the European Communities, which is today the CJEU. While the Coal and Steel Court decided only 26 cases during the first ten years of its existence, today, the CJEU's docket comprises roughly 1600 cases per year. ${ }^{28}$ To cope with this increased workload, the Court itself has grown, encompassing since 1989 the European Court of Justice (ECJ) and the General Court (GC). Together they currently employ 84 judicial members $^{29}$ and a staff of 2174 people. $^{30}$ The CJEU's administration encompasses a language department of 994 interpreters and translators, the latter translating no less than 1112924 pages in 2017; ${ }^{31}$ a research, documentation and library department of 101 people, who scan incoming applications and provide comparative law research; a total of 537 law clerks and assistants working in the judicial members' cabinets, and roughly 300 people working in administrative, logistical and IT services. ${ }^{32}$

The first remarkable development in judicial governance at the CJEU is the fact that, despite these massive changes, the original model of self-government has, with some adaptation, remained intact. The most important administrative decisions still remain in

\footnotetext{
${ }^{26}$ On the conception of international judges as 'ambassadors for the state', RUTH MACKENZIE ET AL., SELECTING INTERNATIONAL JUdGES: PRINCIPLE, PROCESS, AND POLITICS 60 (2010).

${ }^{27}$ Nicole Condorelu-BRAun, Commissaires et Juges dans les Communautes EURopeennes 108-109 (1972).

${ }^{28}$ The ECJ completed 699 cases in 2017 the General Court 895 cases (JUDICIAL ACTIVITY REPORT 101 and 207) (2017), https://curia.europa.eu/jcms/upload/docs/application/pdf/2018-04/_ra_2017_en.pdf.

${ }^{29}$ The ECJ currently has 28 judges and 11 Advocates General, the GC 45 judges (1 December 2018).

${ }^{30}$ As of 31 December 2017, https://curia.europa.eu/jcms/jcms/P_80908/en.

31 Court OF Justice OF the EuROPEAN UNION, MANAGEMENT REPORT 14 (2017); https://curia.europa.eu/jcms/upload/docs/application/pdf/2018-06/rapport_gestion_2017_en-web.pdf.

${ }^{32} / d ., 55$.
} 
the judicial members' hands (1.). In two respects, however, the CJEU's governance model has been further developed. While regulating judges' and Advocates' General conduct in office has always been the Court's sole competence, today a dense net of rules defines the duties and obligations of CJEU members (2.) As regards the appointments of new judges and Advocates General the Court remains on the sideline. However, the power of Member States to appoint new CJEU members at their will has been attenuated through the establishment of an expert panel that assesses candidates' qualifications and which has gained an influential role in the selection process (3.).

\section{Collegial self-government in an enlarged Court}

The CJEU's institutional growth has brought two challenges to its internal governance structure. First, an administration that, due to its size and multiple tasks, requires significantly more administrative guidance and management than during the Court's early years. ${ }^{33}$ And second, the challenge of upholding the collegial character of administrative decision-making in an institution that encompasses two courts, the ECJ and the GC. The Court has reacted to these challenges by creating a multiplicity of internal self-government bodies that stand in close connection with each other.

The ECJ and the GC today both have their own self-government structure. The GC has its own President, responsible to represent the GC and direct its judicial business, its own Vice-President, and a Registrar. ${ }^{34}$ It has a separate administrative meeting ${ }^{35}$ and its own committees. Yet, when it comes to questions that concern the CJEU as a whole, the ECJ's réunion générale, in which only ECJ judges and Advocates General take part and have a vote (and not the GC judges), is the central decision-making body. ${ }^{36}$ The issues decided here include questions of budget, the appointment of administrative directors, proposals on modifications to the CJEU's Statute or the Court's input in intergovernmental conferences. ${ }^{37}$

Due to the complexity and number of decisions to be taken for the CJEU as a whole, they are prepared by a number of committees. The most important is the ECJ administrative committee. The administrative committee is a key venue to also include the GC into the CJEU'S overall governance structure. The ECJ administrative committee is headed by the

\footnotetext{
${ }^{33}$ See already, Grass, supra note 4.

${ }^{34}$ Article 9 GC RoP.

${ }^{35}$ Article 42 para 1 GC RoP.

${ }^{36}$ Article 25 ECJ RoP.

${ }^{37}$ Jean-Claude Bonichot, Le métier de juge à la Cour de justice des Communautés européennes, 16 REVUE DES AFFAIRES EUROPEENNES 531, 535 (2007/08).
} 
ECJ's President and composed of him, six further ECJ members, the President of the GC and a further GC member. ${ }^{38}$ The committee members are appointed for the three years of an ECJ President's term in office. All major employment and work-related issues pass through the administrative committee, as do budgetary questions. ${ }^{39}$ Moreover, it is involved in the recruitment of high-level officials, and also conducts interviews on those occasions ${ }^{40}$ or decides on the restructuring of the Court's service departments. ${ }^{41}$ Every ECJ and GC member is informed about the committee's agenda and is equipped with all relevant documents and the minutes of the committee's sessions. ${ }^{42}$ Every question the administrative committee tackles, can be reassigned to the ECJ's réunion générale, either by the committee itself or at the request of a member of the Court. ${ }^{43}$

While this complex institutional arrangement ensures broad information and a chance to participate for all CJEU judicial members, one should certainly not overstretch the notion of collegial self-government in a court of the CJEU's size. Important asymmetries and exceptions to collegiality exist. A first important point concerns the $\mathrm{GC}^{\prime}$ 's overall position in CJEU governance. While the GC is represented in the ECJ's administrative committee and the ECJ regularly consults with the $\mathrm{GC}^{44}$ in principle, the ECJ controls the CJEU's resources. ${ }^{45}$ For a long time, the GC has complained about its dependence on the ECJ's goodwill when it comes to its institutional resources. ${ }^{46}$ On an individual level, not all CJEU

${ }^{38}$ Art. 3 of the Décision de la Cour de justice du 20 octobre 2015 relative au comité administratif de la Cour (on file with the author).

${ }^{39}$ For instance, Procès-verbal de la réunion spéciale du comité administratif du 24 mars 2014 (on file with the author).

${ }^{40}$ For instance the hiring process of the Court's 'Conseiller juridique pour les affaires administratives', see Procèsverbal de la réunion du comité administratif du 6 juillet 2015, at 1 (on file with the author).

${ }^{41}$ On the re-structuring of the Court's communications department, Procès-verbal de la réunion du comité administratif du 5 novembre 2014 (on file with the author).

${ }^{42}$ Art. 6, supra note 38 .

${ }^{43}$ Id., Art. 7.

${ }^{44}$ Van der Woude, supra note 4 , at 71.

${ }^{45}$ According to Article 12 CJEU Statute, officials and other servants are attached to the Court of Justice and responsible to the ECJ's Registrar under the authority of the ECJ President. While, according to Article 52 CJEU Statute, certain officials are directly responsible to the Registrar of the GC under the authority of the President of the GC, they nevertheless remain attached to the ECJ, which is, according to Article $9 \mathrm{ECJ}$ RoP responsible for all CJEU resources. As van der Woude, supra note 4, at 70, highlights, Article 9 para 3 ECJ RoP ('The President shall ensure the proper functioning of the services of the Court.'), suggests, notably in its non-English version, that all resources are attached to the $\mathrm{ECJ}$ and the $\mathrm{GC}$ does not have own resources.

${ }^{46}$ See then-GC President Bo Vesterdorf's submission to the discussion circle on the Court of Justice in the Convention on the Future of Europe, Oral presentation by Bo Vesterdorf, President of the Court of First Instance of the European Communities, to the 'discussion circle' on the Court of Justice on 24 February 2003; available at: https://www.cvce.eu/. 
members have an equally influential place in the Court's administrative governance. Notably, the ECJ President takes a special place. He or she is appointed by the fellow ECJ judicial members for a renewable term of three years and presides at the réunion générale, represents the Court to the outside, and has the task to 'ensure the proper functioning of the services of the Court. ${ }^{47}$ The President's special place does not only result from the prestige of the position and the administrative tasks attached to this office, but also from the fact that the ECJ President has full discretion to assign cases to ECJ judges. ${ }^{48}$ This presents the potential to reward judges with high-profile cases, or conversely, assign rather technical or low-profile cases. ${ }^{49}$ According to reports, the President's outstanding position has been used in the past to steer the Court's administrative agenda. ${ }^{50}$

\section{Being a European judge: codes and statistics}

A central element of judicial governance concerns the regulation of judicial members' conduct while in office. What duties does a European judge or Advocate General have? And who may remind her of these duties? Following the ICJ's example, the principled competence of the Court to decide itself on the obligations of judicial members and on disciplinary matters had already existed in the Coal and Steel Court. However, the early years of the European judiciary were rather lenient times. Rules on judicial conduct, such as the duty to reside at the Court's seat, ${ }^{51}$ or the duty not to engage in political or administrative activities, ${ }^{52}$ were not taken too seriously. Coal and Steel Court members regularly commuted to their home countries or continued working, often as advisors, for their governments. ${ }^{53}$ This leniency is a thing of the past. The duties of CJEU members are today regulated in detail and their observance is checked.

\footnotetext{
${ }^{47}$ Article 9 para 3 ECJ RoP.

${ }^{48}$ Jean Quatremer, La justice européenne au bord de la crise de nerfs, LIBÉRATION: COULISSES DE BRUXELLES (Apr. 26, 2015), http://bruxelles.blogs.liberation.fr/2015/04/26/la-justice-europeenne-au-bord-de-la-crise-de-nerfs (relying on an anonymous source from within the Court who describes a concentration of powers with then-President Skouris).

${ }^{49}$ See Article 15 para 1 ECJ RoP.

${ }^{50}$ For an example see the alleged attempts by former President Skouris to create an attractive job in the Court's administration for his former chef de cabinet against the opposition of inter alia the Court's Registrar, see Jean Quatremer, Copinage et clientélisme à la Cour de justice européenne, LIBÉRATION: COULISSES DE BRUXELLES (JUne 8, 2015), http://bruxelles.blogs.liberation.fr/2015/06/08/copinage-et-clientelisme-la-cour-de-justice-europeenne.

${ }^{51}$ Article 9 Coal and Steel Court Statute.

${ }^{52}$ Article 32 Coal and Steel Treaty and Article 4 para 3 Coal and Steel Court Statute; only if the Council agreed by a two-thirds majority, could the judges be authorized to engage in an unpaid or gainful occupation.

${ }^{53}$ A most vivid example is, what has been called, the Affaire Rueff. Already during the year 1958, Jacques Rueff, the French Coal and Steel Court judge, had led a French government committee in charge of restructuring public finances. In November 1959 he officially resigned as a judge, to return to Paris to become vice-president of a committee in charge of reforming the French economy. Both the obligation to continue his work as a judge until a
} 
The two most important set of rules are the CJEU's Code of Conduct and the Court's case management system. The Court's Code of Conduct was first introduced in $2007^{54}$ and revised in $2016 .{ }^{55}$ It includes rules on independence and integrity (Article 3), impartiality (Article 4), a duty to declare personal interests (Article 5), an obligation of loyalty towards the institution (Article 6), and rules on discretion (Article 7). Furthermore, Article 8 of the Code of Conduct makes all external activities, from participating in conferences or seminars to teaching, to assuming duties in foundations, subject to prior authorization by the Court. The focus is, as Article 2 of the Code holds, on ensuring that CJEU members devote themselves fully to the performance of their duties. Article 10 of the Code sets up a 'committee of eldest', responsible for ensuring its proper application. The committee is composed of the ECJ President and the three ECJ members who have been longest in office. If a member of the GC is concerned, the GC President, the GC Vice-President and another member of the GC take part in the deliberations of the committee. Little is known about the actual working of the disciplinary committee. It seems to work as a backup accountability mechanism that is rarely used. It has notably been invoked in a heated conflict between then-ECJ President Skouris and GC President Jaeger over the idea to double the number of GC judges. ${ }^{56}$ In 2014 another possible violation of the Code has been examined. $^{57}$

In the day-to-day business, the strongest effect on CJEU members' conduct arguably stems from the Court's case management system. ${ }^{58}$ As the Court describes it itself, it employs 'a

successor had been named (Article 5 ECSC Statute) and the duty not to engage in administrative or political activities (Article 4 ECSC Statute) had been ignored. This created a highly uncomfortable situation for the Court. During one year, it had to exclude the youngest of its members from its deliberations, deciding with five judges only, in order to conform with the obligation to sit in unequal numbers. It was not until September 1960 that France reappointed a judge to the Court: surprisingly, and quite embarrassingly for the Court, an unmotivated Jacques Rueff, who stayed on the Court for another two years until he was again urgently needed in Paris; see, Antonin Cohen, Juge et expert. L'Affaire Rueff ou la codification des règles de la circulation internationale, 59 CRITIQUe INTERNATIONALE 69 (2013).

${ }^{54}$ Code of Conduct [2007] OJ C223/1.

${ }^{55}$ Code of Conduct for Members and former Members of the Court of Justice of the European Union [2016] OJ C483/1.

${ }^{56}$ A letter from then-ECJ President Vassilios Skouris to GC President Marc Jaeger was leaked. In this letter Skouris alleged that Jaeger had damaged the CJEU's position by communicating directly with the President of the COREPER on the GC's institutional reform - a prerogative of the ECJ President. Skouris mentions in this letter that the committee under Article 7 of the (2007) Code of Conduct has, in light of these events, decided not to grant additional staff to the GC; see Duncan Robinson, The 1st rule of ECJ fight club... is about to be broken, FINANCIAL TIMES: BRUSSELS BLOG (April 27, 2015), http://blogs.ft.com/brusselsblog/2015/04/27/the-1st-rule-of-ecj-flight-clubis-about-to-be-broken.

${ }^{57} 2014$ discharge. Questionnaire to European Court of Justice, at 6 (on file with the author).

${ }^{58}$ See, Vassilios Skouris, Höchste Gerichte an ihren Grenzen - Bemerkungen aus der Perspektive des Gerichtshofes der Europäischen Gemeinschaften, in DIE ORDNUNG DER FREIHEIT. FESTSCHRIFT FüR CHRISTIAN STARCK ZUM SIEBZIGSTEN GEBURTSTAG 991, 997 (Rainer Grote et al eds., 2007). 
constant case-flow control of each step of the procedure on the basis of complex and numerous indicators. ${ }^{59}$ An early warning system is in place, and 'the President/President of Chamber [intervenes] in time in order to discuss the matter with the Judge Rapporteur, eventually the Advocate General concerned. ${ }^{60}$ In the GC, case management seems to be even more stringent than in the ECJ. Lists are kept that contain time limits for different steps in the preparation of judgments, set out delayed cases and measures to eliminate the delays, and show the number of cases closed by each judge per quarter and per year. ${ }^{61}$ Indeed, anecdotal evidence shows that the CJEU's case management system creates real pressure. In a rather unusual step, after a couple of months in office, British ECJ judge Christopher Vajda criticized, in an internal memo, the unrealistic rhythm imposed on the judges. ${ }^{62}$ Excessive pressure at the CJEU has also been brought up by other Court members. ${ }^{63}$

\section{Selecting CJEU members: the new role of experts}

A final important development in the governance of the Court concerns the selection of new CJEU members. Until 2009 the normative framework for selecting judges and Advocates General had hardly been altered. Every Member State appointed her candidate for the bench while in relation to nominations by the other Member States the principle 'live and let live' prevailed. ${ }^{64} \mathrm{~A}$ judge or Advocate General proposed by a Member State would quasi-automatically be appointed to the CJEU. In recent years, however, the situation has changed. Through the 2009 Lisbon Treaty, Article 255 TFEU has been inserted into the Treaties. It sets up an advisory panel (the 255 Panel) for the selection of CJEU members. ${ }^{65}$ The 255 Panel is composed of seven experts, mainly senior national and

\footnotetext{
${ }^{59} 2013$ discharge questionnaire to the European Court of Justice, at 5 (on file with the author).

${ }^{60} / d$.

${ }^{61}$ Dehousse, supra note 4, at 51-52.

${ }^{62}$ See, Dominique Seytre, Pour une liste de juges retardaires?, LE JEUDI, (June 6, 2013), http://jeudi.lu/pour-uneliste-de-juges-retardataires.

${ }^{63}$ Most forcefully by Eleanor Sharpston, Making the Court of Justice of the European Union More Productive, 21 MAASTRICHT JOURNAL OF EUROPEAN AND COMPARATIVE LAW 763 (2014).

${ }^{64}$ Henri de Waele, Not Quite the Bed that Procrustes Built. Dissecting the System for Selecting Judges at the Court of Justice of the European Union, in SELECTING EUROPE'S JUdGeS. A CRITICAL REVIEW of THE APPoINTMENT PROCEDURES to THE EUROPEAN COURTS 24, 49 (Michal Bobek ed., 2015).

${ }^{65}$ Article 255 TFEU, in its present form, goes back to the European Convention preparing the draft Treaty establishing a Constitution for Europe in the early 2000s, and to the fear of the rise of 'political nominations' in particular in light of the upcoming enlargements of the Union. See René Barents, The Court of Justice in the Draft Constitution, in 11 MAASTRICHT JouRnal OF EUROPEAN AND COMPARATIVE LAW 121, 139 (2004); see also Thorbjörn Björnsson and Yuval Shany, The Court of Justice of the European Union, in ASSESSING THE EFFECTIVENESS OF INTERNATIONAL COURTS 292 (Yuval Shany ed., 2014).
} 
former European judges, currently headed by former ECJ judge, Christiaan Timmermans. ${ }^{66}$ Its task is to prepare the final selection decision of the 'representatives of the governments of the Member States ${ }^{\prime 67}$ by rendering opinions on candidates' qualifications. The Panel bases its decisions on a number of documents, notably the candidate's CV, the reasons of the candidate to apply for the position and the reasons of the government proposing her, information on the national pre-selection procedure, and works published by the candidate. Unless the candidate is proposed for re-appointment, an interview of one hour is conducted. $^{68}$

To be sure, the establishment of the 255 Panel does not establish judicial self-government in the sense that the CJEU has a say in the selection of new members. However, at least indirectly, it has led to increasing the Court's influence on selection processes. ${ }^{69}$ The ECJ President presents a proposal for the Panel's composition, ${ }^{70}$ which the governments of the Member States so far have followed. ${ }^{71}$ This leads, as commentators have observed, to a factual right of co-determination in the composition of the Panel. ${ }^{72}$

\footnotetext{
${ }^{66}$ For the current composition of the Panel, see Council Decision (EU, Euratom) 2017/2262 of 4 December 2017 appointing the members of the panel provided for in Article 255 of the Treaty on the Functioning of the European Union.

${ }^{67}$ See Articles 253 and 254 TFEU.

${ }^{68}$ In detail, de Waele, supra note 64 , at 35-39.

${ }^{69}$ Alberto Alemanno, How Transparent is Transparent Enough? Balancing Access to Information Against Privacy, in Selecting Europe's Judges. A CRitical Review of the Appointment Procedures to the European CourTs, supra note 64, 202, at 204 ('some embryonic form of unintended judicial self-government'); in this sense, see also Tomas Dumbrovský, Bilyana Petkova \& Marvin Van der Sluis, Judicial Appointments: The Article 255 TFEU Advisory Panel and Selection Procedures in the Member States, 51 COMMON MARKET LAW REVIEW 455, 481-482 (2014) (speaking of the potential for a 'subtle move' in the direction of judicial self-government).

${ }^{70}$ Article 255 para 2 TFEU.

${ }^{71}$ As regards the first panel proposed by then-President Skouris, see Council of the European Union, Recommendation concerning the composition of the panel provided for in Article 255 TFEU, Doc 16858/13 JUR 600 INST 638 COUR 92 + ADD (December 4, 2013), and the approval without discussion as an A-item by the Council of the EU, Council of the European Union, Council Decision appointing the members of the panel provided for in Article 255 TFEU = Adoption, Doc. 16858/13 JUR 600 INST 638 COUR 92 + ADD 1 (January 22, 2014).

72 Ulrich Karpenstein, Artikel 255 AEUV, in DAS RECHT DER EUROPÄISCHEN UNION, margin number 11-12 (Eberhard Grabitz, Meinhard Hilf \& Martin Nettesheim eds., 2017). Moreover, according to Article 255 TFEU, the ECJ President has also proposed the operating rules of the Panel adopted in 2010. With only cosmetic linguistic changes by the Council they had been approved. For the ECJ President's proposal see, Council of the European Union, Recommendation relating to the operating rules of the panel provided for in Article 255 TFEU, Doc. 5195/10 JUR 5 INST 2 COUR 1 (January 11, 2010); for the Council's final decision, Council Decision 2010/124/EU relating to the operating rules of the panel provided for in Article 255 of the Treaty on the Functioning of the European Union, O.J. L50/18, Annex (2010).
} 
The Panel's opinions are legally non-binding. However, in practice, the Panel has gained important influence. Its principled lever lies in the structure of appointments. The Member States appoint judges and Advocates General by unanimity and the 255 Panel's opinions are communicated to all Member States. Hence, all Member States would have to agree to ignore the Panel's views as regards a candidate, a situation that is very unlikely to occur. ${ }^{73}$ From March 2010 to February 2018 the Panel has delivered a total of 147 opinions, 74 of which were on candidates who were proposed for a renewal of office and 73 on candidates for a first term of office. While candidates for a renewal of office were all deemed suitable, of the 73 opinions on candidates for a first term of office, 14 opinions $\left(19,2\right.$ percent) were unfavorable. ${ }^{74}$ All of the Panel's 14 negative opinions have been followed by the Member States and accordingly new candidates have been proposed. ${ }^{75}$

Figure 1: The selection of CJEU judges post-Lisbon

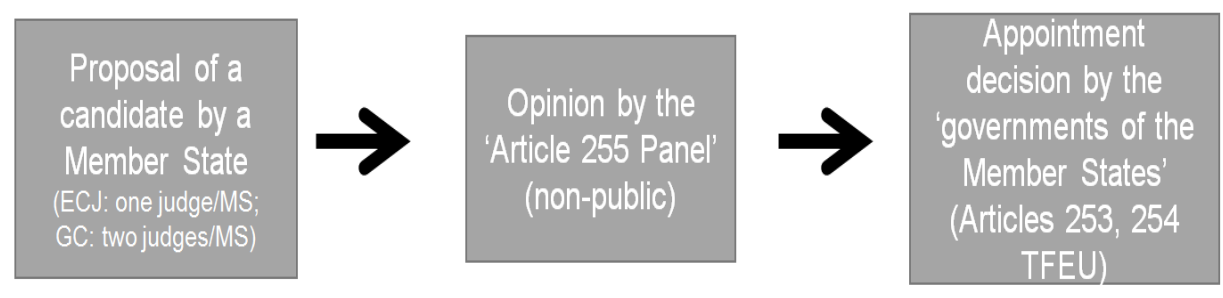

\section{The CJEU's governance model and the Court's institutional success}

In the preceding section, we have examined the genesis of the CJEU's governance model and its defining features. In this section, we will engage in an analysis of the effects of this specific version of JSG for the Court as an institution. The CJEU is considered one of the most powerful courts worldwide. ${ }^{76}$ Surveys show that the confidence of the general public in the Court is high. ${ }^{77}$ Moreover, the Court's independence is comparatively strong. ${ }^{78}$ In

\footnotetext{
${ }^{73}$ Michal Bobek, Epilogue. Searching for the European Hercules, in SELECTING EUROPE'S JUdges. A CRITICAL REVIEW OF the APPointment Procedures to the European Courts 282 (Michal Bobek ed., 2015).

${ }^{74}$ Fifth Activity report of the Panel Provided for by Article 255 of the Treaty on the Functioning of the European Union, 28 February 2018, at 15.

${ }^{75}$ Id. , at 14.

${ }^{76}$ From the vast literature on the topic see only ANTHONY ARNULL, THE EUROPEAN UNION AND ITS COURT OF JUSTICE (2006); Karen Alter, The European Court's Political PoWer (2009).

${ }^{77}$ The European Court of Justice is the most trusted of all institutions of government assessed in Eurobarometer surveys; see R. Daniel Kelemen, The political foundations of judicial independence in the European Union, 19 Journal of EuRopean Public Policy 43 (2012).

78 See louis hancisse, Amanda McMenamin, Mark Perera \& Ronny Patz, The European Union INTEgRITy System 125 (2014).
} 
line with the broader objectives of this special issue, ${ }^{79}$ I will link the main findings in EU scholarship on the conditions for public confidence in the Court (I.), its judicial authority (II.) and independence (III.) to the specific features of its governance model.

\section{Avoiding controversy: JSG and public confidence}

Much of the discussion on the structure of and reasons for public confidence in the CJEU is coined by a set of articles published in the 1990s by Greg Caldeira and James Gibson. ${ }^{80}$ Based on surveys, they assessed public confidence in the European judiciary. In a nutshell, they argued that the general public knows too little about the Court to make informed judgments and that it therefore relies on proxies to assess its confidence in the CJEU. As Caldeira and Gibson summarize their findings: 'In the absence of information about the Court of Justice, ordinary citizens depend on this institution's connection with the EU, as well as its association with broad political and legal values such as the rule of law and individual liberty. ${ }^{81}$ Eric Voeten has recently updated this analysis. He comes to the conclusion that although the CJEU is today more frequently in the public limelight, trust in the Court is still largely correlated to people's general trust in the EU and in domestic judicial systems. This leads Voeten to argue that the Court, 'should not worry on a daily basis about the general public other than avoiding decisions that lead to public outcries, although these may not be perfectly predictable. ${ }^{82}$ The development of levels of trust in the Court (figure 2) support these findings. The two major declines in trust in the Court in the early 1990s and between 2010 and 2012 can be linked to two major crises of the European integration project that affected trust in the EU as such: the EU-skeptical environment surrounding the ratification of the Maastricht Treaty and the financial and sovereign debt crisis.

\footnotetext{
${ }^{79}$ See, Kosař, supra note 3.

${ }^{80}$ Gregory A. Caldeira \& James L. Gibson, The Legitimacy of the Court of Justice in the European Union: Models of Institutional Support, 89 AMERICAN PolitiCAL SCIENCE REVIEW 356 (1995); James L. Gibson and Gregory A. Caldeira, Changes in the Legitimacy of the European Court of Justice, 28 BRITISH JOURNAL OF POLITICAL SCIENCE 63 (1998).

${ }^{81}$ Caldeira \& Gibson, The Legitimacy of the Court of Justice in the European Union: Models of Institutional Support, supra note 80 , at 365 .

${ }^{82}$ Eric Voeten, Public Opinion and the Legitimacy of International Courts, 14 THEORETICAL INQUIRIES IN LAW 411, 416 (2013).
} 
Figure 2: Public trust in the CJEU (Eurobarometer results)

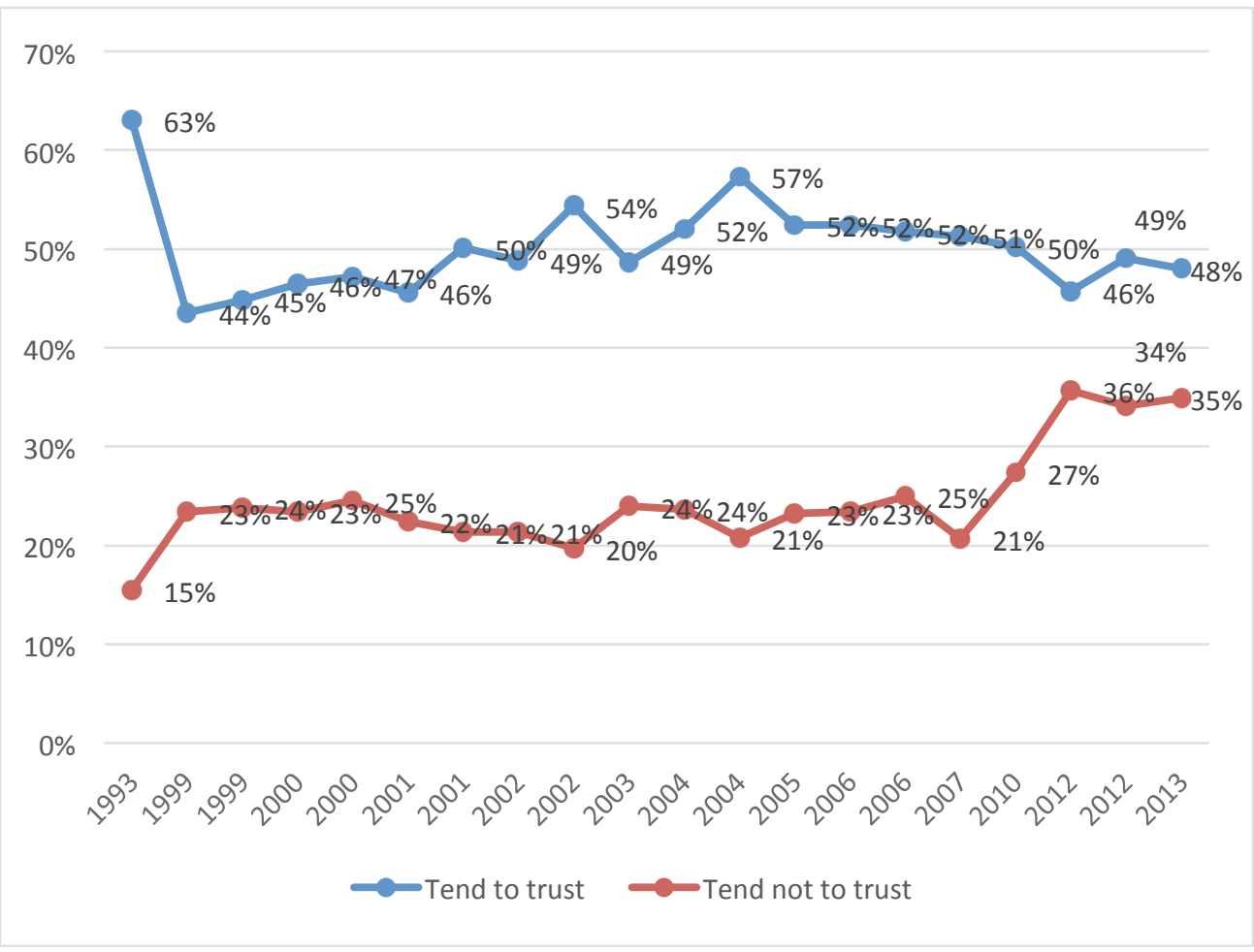

Given how the public forms its opinion on the CJEU, the only important requirement, as regards the Court's administrative governance, seems to be that it runs smoothly. In principle, the CJEU's governance structure is well suited to do the job, keeping and managing conflicts inside the Court. The involvement of all CJEU members in the administration of the Court, in particular through its administrative committee work, creates a decision-making structure that provides procedural means to manage disagreements internally. Indeed, the only example of a major conflict on judicial government in the CJEU, which received extensive media coverage ${ }^{83}$ concerned an intrainstitutional dispute between the ECJ and the $G C$ on raising the number of judges at the GC. Against the will of the GC, which preferred different measures to enhance its productivity, the ECJ had used its prerogative in legislative reform of the CJEU Statute to push for doubling the number of GC judges. The process led to intensive controversies over

\footnotetext{
${ }^{83} \mathrm{See}$, for instance, Robinson, supra note 56. On a further conflict on the drafting of the CJEU's Code of Conduct, where the GC felt marginalized, see Dominique Seytre, Les juges et le syndrome "Mirza", LE JEUDI (December 8, 2016).
} 
who speaks for the Court vis-à-vis the Member States and the European Parliament, the threat of disciplinary measures against the GC President ${ }^{84}$ and lobbying by the ECJ President with major EU governments. ${ }^{85}$ Yet, this was a singular event and rather special conflict. $^{86}$

Besides such rare disputes, the selection of new judicial members presents moments where the public takes notice of the Court. In the past, the nomination of ill-qualified candidates or politically motivated nominations has been critically discussed in the press. ${ }^{87}$ The establishment of the 255 Panel arguably contributes to changing public perceptions in this regard. When in 2014 a Greek candidate for a vacancy at the GC had received a negative opinion by the 255 Panel, in the Greek press, the Panel was presented as an effective check against personal and political favoritism that was allegedly behind the rejected proposal. $^{88}$ Newspaper reports on rejections of Maltese, ${ }^{89}$ Swedish $^{90}$ and Austrian $^{91}$ candidates by the Article 255 Panel similarly present the Panel in a positive light and as a guarantee for candidates' judicial expertise. In that sense, one could suggest that the establishment of the 255 Panel has indeed strengthened public confidence in selection processes of new judges, which could in turn foster public confidence in the Court. To be sure, more systematic research is required to back up this argument.

\section{Professionalism: JSG and judicial authority}

While public confidence is a side strand in the study of the CJEU, a vast field of research deals with the CJEU's judicial authority i.e. the acceptance and use of the Court's case law

\footnotetext{
${ }^{84}$ See Robinson, supra note 56.

${ }^{85}$ Dehousse, supra note 4.

${ }^{86}$ For the whole story, see Alberto Alemanno \& Laurent Pech, Thinking Justice Outside the Docket: A Critical Assessment of the Reform of the EU's Court System, 54 COMMON MARKET LAW REVIEW 129 (2017).

${ }^{87}$ See Barents, supra note 65, at 139.

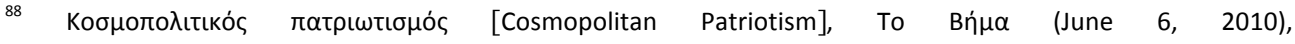
http://www.tovima.gr/opinions/article/?aid=335911.

89 Chief Justice fails in bid for European Court job, TIMES OF MALTA (March 3, 2016) https://www.timesofmalta.com/articles/view/20160303/local/chief-justice-fails-in-bid-for-european-courtjob.604431.

${ }^{90}$ Stefan Strömberg anses ej lämplig som EU-domare [Stefan Strömberg is not considered suitable as EU judge], REALTID.SE (August 3, 2012); http://www.realtid.se/stefan-stromberg-anses-ej-lamplig-som-eu-domare.

${ }^{91}$ Regierung schlägt Grazer Professor Kumin als EuGH-Richter vor [Government proposes Professor Kumin from Graz as ECJ judge], DIE PRESSE (Nov. 12, 2018); https://diepresse.com/home/ausland/eu/5528760/Regierungschlaegt-Grazer-Professor-Kumin-als-EuGHRichter-vor.
} 
by domestic courts and governments. ${ }^{92}$ Compared to other courts beyond the state, the CJEU's authority is particularly strong. In contrast to the question of public confidence, where general public perceptions count, for judicial authority, the Court's appearance to key compliance constituencies matters most. Notably domestic courts and Member State administrations are central in this regard. ${ }^{93}$ Compared to the general public, the Court's compliance constituencies are likely to take a closer look at the professional expertise of judges and the well-functioning of the Court's administration to assess the Court and adjust their compliance and cooperation behavior accordingly. ${ }^{94}$

For domestic judges, an important question when cooperating with the ECJ, notably through the preliminary reference procedure, concerns their impressions of CJEU judges' credentials, loyalties and expertise. As Michal Bobek, putting himself in the shoes of a domestic judge, asks poignantly: 'Do those people in that Luxembourg ivory tower/glass house/sky castle understand what is going on down here?' ${ }^{95}$ From this perspective, two features of the CJEU's governance model might help foster the trust domestic judges invest in the CJEU. First, the fact, that, in terms of judicial governance, the CJEU very much looks like a domestic court. The Court's Code of Conduct, an instrument not existent at the CJEU's sibling in Strasbourg, ${ }^{96}$ and the tight regime of case management present CJEU judges as committed and hard working professionals, who are exposed to the same exigencies as a standard domestic judge (time pressure, performance targets, etc.). Second, also the Article 255 Panel can support such an impression. In the scholarly literature on the topic, which is often authored by practicing lawyers, the assessment of the Panel is generally favorable and its contribution to the quality of CJEU judges and their independence is underlined. ${ }^{97}$ In that sense it might also help that the 255 Panel is

\footnotetext{
${ }^{92}$ Alec Stone Sweet, The European Court of Justice and the Judicialization of EU Governance, in 5 LIVING REVIEWS IN EUROPEAN GOVERNANCE 8 (2010).

${ }^{93}$ See for instance, Anne-Marie Burley and Walter Mattli, Europe before the Court: A Political Theory of Legal Integration, 47 InTERnATIONAL ORganization 41 (1993); Olof Larsson, Daniel Naurin, Mattias Derlén \& Johan Lindholm, Speaking law to power: the strategic use of precedent of the Court of Justice of the European Union, 50 Comparative Political StUdies 879, 884-886 (2017).

${ }^{94}$ On trust as a key factor for the cooperation of domestic judges with the Court, see Juan A. Mayoral, In the CJEU Judges Trust: A New Approach in the Judicial Construction of Europe, 55 JOURNAL OF COMMON MARKET STUdIES 551 (2017).

${ }^{95}$ Michal Bobek, Of Feasibility and Silent Elephants: The Legitimacy of the Court of Justice through the Eyes of

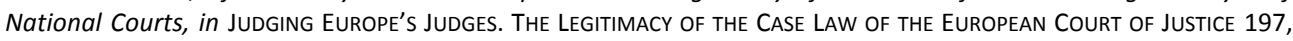
218 (Maurice Adams, Henri de Waele, Johan Meeusen \& Gert Straetmans eds., 2013).

${ }^{96}$ See, Başak Çalı \& Stewart Cunningham, Judicial Self Government and the sui generis case of the European Court of Human Rights, 19 GERMAN L.J. (2018).

${ }^{97}$ See for instance, Karpenstein, supra note 72; further, Dominique Ritleng, The Independence and Legitimacy of the European Court of Justice, in INDEPENDENCE AND LEGITIMACY IN THE INSTITUTIONAL SYSTEM OF THE EUROPEAN UNION 83, 100 (Dominique Ritleng ed., 2016).
} 
composed of highly renowned domestic judges, sending a signal to domestic courts that they are represented in the selection of the European judiciary. ${ }^{98}$

\section{Shielding CJEU members: JSG and judicial independence}

Closely linked to the question of judicial authority, is the issue of independence. In a 2014 study, Transparency International has concluded that there is no evidence that the Member States, other entities or individuals exercise undue influence on the Court's decisions or on individual judges. ${ }^{99}$ That judges' de facto independence is strong is surprising given that their de jure independence is generally seen as a weak spot in the Court's institutional design. For a long time, there has been a critique that the short term of office of six years ${ }^{100}$ and the possibility of indefinite reappointments might undermine judicial independence, making judges vulnerable to political influence if they seek to be reappointed. ${ }^{101}$

However, in practice, these threats are reduced through a number of institutional mechanisms that foster the anonymity of CJEU members. The absence of dissenting or concurring opinions is a first instrument to shield judges from undue influence. ${ }^{102}$ From the perspective of JSG, the intensive regulation and peer review of judicial conduct ${ }^{103}$ arguably contribute to Court members' de facto independence. All external activities require prior authorization by the CJEU members' peers. Judges and Advocates General are hence informed on the outside activities of their colleagues, which turns questions of independence from a virtue of the individual Court member to being also a matter that affects the whole Court. A similar rule has been adopted for the Court's law clerks. They need to get permission to take part in external activities by their judge or Advocate General and the Court's President. The content of both, publications as well as oral

\footnotetext{
${ }^{98}$ Bobek, supra note 73, at 303. On the current Panel sit for instance Carlos Lesmes Serrano, President of the Spanish Supreme Court; Andreas Voßkuhle, President of the German Federal Constitutional Court; and Mirosław Wyrzykowski, a former judge at the Polish Constitutional Court.

${ }^{99}$ See Hancisse, McMenamin, Perera \& Patz, supra note 78, at 125.

${ }^{100}$ Article 253 paragraphs 1 and 4 and Article 254 paragraph 2 TFEU.

101 Jiří Malenovsky, Les éléments constitutifs du mandat des juges de la Cour de justice à l'épreuve du temps: l'iceberg commence à fondre, 4 IL DIRITTO DELL'UNIONE EUROPEA 801, 817-823 (2011); from the early years, HANSULRICH BÄCHLE, DIE RECHTSSTELLUNG DER RICHTER AM GERICHTSHOF DER EUROPÄISCHEN GEMEINSCHAFTEN 129 (1961).

${ }^{102}$ See, for instance, Josef Azizi, Unveiling the EU Courts' Internal Decision-Making Process: A Case for Dissenting Opinions? 12 ERA FORUM 49 (2011).

${ }^{103}$ See, above, Part B.II.2.
} 
presentations at conferences or other events, needs to be communicated at least one month in advance. ${ }^{104}$

This peer review procedure is complemented by the work of the Court's press department, which serves as a filter for the CJEU's contacts with the outer world. In its relations with the public and the press, the Press department observes a strict policy on what kind of case-relevant information can be released. ${ }^{105}$ For instance, before the hearing, neither the names of the judges composing the bench nor of the Advocate General writing the Opinion must be given away. Also, the status of the proceedings, the date of the deliberations, or the closure of the written part of the proceedings have to be held back. The press department, moreover, works as a filter and buffer for interviews with members of the Court. Every interview needs to be organized through the department's Head of Unit. If accepted by the member of the Court, an official from the department is present at interviews. Moreover, every press interview is read and declassified by the press department. $^{106}$ To be sure, such mechanisms cannot guarantee CJEU members' independence, but they create an environment, where securing independence is seen as a collective task.

\section{The Achilles' heels of JSG: transparency and accountability}

So far, we have discussed the positive effects of the CJEU's model of JSG. It is to the more challenging aspects that we turn now. There are a number of thorny issues strong forms of JSG generally raise, notably ensuring that an institution does not develop a life of its own and that a self-governed court and its judicial members can be held accountable in case of mismanagement. ${ }^{107}$ At the CJEU, questions of transparency (I.) and accountability (II.) in relation to the Court's administrative tasks have been tackled by and large in a convincing manner. Nevertheless, there remain a number of points where room for improvement exists.

\section{Transparency and JSG at the CJEU}

Compared to most international courts, ${ }^{108}$ JSG at the CJEU is bound to respect demanding standards of transparency. When acting in an administrative capacity, the CJEU has, in

\footnotetext{
${ }^{104}$ Article 3 para 1 subpara 3 and Article 4 para 1 Décision du 17 février 2009 portant adoption de règles de bonne conduite des référendaires (on file with the author).

${ }^{105}$ Vademecum: Unité de Presse et de l'Information (June 2015), (on file with the author) at 16.

${ }^{106} / d$., at 13.

${ }^{107}$ See, Kosař, supra note 3.

${ }^{108}$ See, Çalı \& Cunningham, supra note 96.
} 
principle, to conform to the same transparency requirements as any other EU institution. ${ }^{109}$ Since the early 2000s, with the EU's overall focus on good governance, these requirements have become more demanding. According to Article 15 paragraph 3 TFEU, the Court, when performing administrative tasks, has to grant full access to documents. ${ }^{110}$ While the Court does not publish a list of administrative documents for which access can be requested, ${ }^{111}$ if you know what you are looking for, the system works well. ${ }^{112}$ To be sure, where to draw the line to documents drafted in a judicial capacity is a tricky question. $^{113}$ Gradually, the Court is even becoming more proactive in providing information, such as on the outside activities of its members, which are published online. $^{114}$

An important gap in terms of transparency concerns the activities of the 255 Panel. Despite its influential role in judicial appointments, the Panel does not publish its assessments on individual candidates' suitability for office. They are only submitted to the Member States. All requests for being granted access to the Panel's opinions have been turned down. ${ }^{115}$ There is certainly a balance to be struck between ensuring, on the one hand, that the best candidates apply and that private data is protected but that, on the other hand, the public is informed about candidates' credentials and can understand the reasons why individual candidates are considered suitable or not. ${ }^{116}$ Yet, at the moment, such balancing is not

109 In detail, Alberto Alemanno \& Oana Stefan, Openness at the Court of Justice of the European Union: Toppling a Taboo 51 COMMON MARKET LAW REVIEW 97, 108-113 (2014).

${ }^{110}$ The procedure for access to documents has been concretized in a decision, which sets out the steps for the application process and regulates review and appeal procedures in case access to documents is denied; see the Decision of the Court of Justice of the European Union of 11 October 2016 concerning public access to documents held by the Court of Justice of the European Union in the exercise of its administrative functions (2016/C 445/03).

${ }^{111}$ Alemanno \& Stefan, supra note 109, at 113.

${ }^{112}$ This article, being based on a number of documents that have been received through the CJEU's transparency regime, is good proof of this.

${ }^{113}$ Alemanno \& Stefan, supra note 109, at 113-116.

114 For the first time, during the 2014 budgetary discharge procedure, the Court revealed to the European Parliament a list of 158 outside activities of its members. However, it was not mentioned which CJEU members took part in the individual events, see CJEU, Décharge 2014. Questionnaire adressé à la Cour de justice. Complément de réponse aux questions $n^{\circ} 9$ et 10: Liste des activités exercées par les Membres des trois juridictions ayant eu un impact sur le budget de l'Union européenne; for the year 2017 a list of outside activities linking CJEU members names to the events has been published by the Court online; see https://curia.europa.eu/jcms/upload/docs/application/pdf/2018-02/tra-doc-en-div-c-0000-2018-20180088505_01.pdf.

${ }^{115}$ For the reasons given by the Council and the critque see, Anastasia Eriksson, Mingzhu Li, Omar Shalaby, Alberto Alemanno \& Paige Morrow, Transparent Selection of Judges for EU Courts: Complaint to the European Ombudsman, HEC Paris Research Paper No. LAW-2017-1239.

${ }^{116}$ On how to strike the balance, see Alemanno, supra note 69. 
performed. Rather, access is completely ruled out. The shielded nature of the Panel's work is not primarily the Court's fault. The Panel is institutionally linked to the Council and not to the Court. Nevertheless, given the CJEU's important role in setting up the Panel, notably by proposing its operating rules, ${ }^{117}$ the Court can be considered somewhat complicit in creating the problems the Panel raises from the perspective of transparency. In the literature, proposals have been made how to improve the situation. ${ }^{118}$

Difficult transparency issues arise when the CJEU leaves the field of court administration stricto sensu and enters the legislative realm. Since the 2009 Treaty of Lisbon, according to Article 281 paragraph 2 TFEU, the Court can initiate changes to its Statute, the European Parliament and the Council decide as co-legislators. Problems such a legislative role for the Court entail, became apparent in the recent controversial process of doubling the number of GC judges. ${ }^{119}$ Being part of the legislative process, the Court engaged in lobbying to promote its proposal. ECJ President Skouris visited the President of the European Parliament, Martin Schulz, other ECJ members met with the European People's Party group. ${ }^{120}$ Moreover, French media reported on a meeting between President Skouris and the German Ministers of Justice and Finance, Heiko Maas and Wolfgang Schäuble, in Berlin to discuss the reform of the GC. ${ }^{121}$ Yet, these visits were not officially communicated. Moreover, documents emanating from the Court in the course of the legislative procedure were often undated, unregistered, unsigned and not made publically available. ${ }^{122}$ Given that such prominent role for the Court in the EU's legislative process is a rather new development, it seems advisable to look how other independent EU institutions handle transparency requirements when they engage in political consultations, for the Court to properly adjust its transparency standards for such cases. ${ }^{123}$

\section{Accountability and JSG at the CJEU}

Accountability is probably the most difficult terrain when thinking about JSG. Even if courts are held accountable for their activities performed in court administration only, the line to negatively affecting a court's judicial independence is easily crossed. This applies in

\footnotetext{
${ }^{117}$ See supra note 72 .

${ }^{118}$ See, notably, Eriksson, Li, Shalaby, Alemanno \& Morrow, supra note 115.

${ }^{119}$ See supra note 56.

${ }^{120}$ Dehousse, supra note 4, at 67.

${ }^{121}$ Jean Quatremer, 'Le superjuge frôle le hors-jeu’, Libération (6/7 June 2015) p. 16.

122 Dehousse, supra note 4, at 65.

${ }^{123}$ Executive Board Members of the European Central Bank, for instance, publish their diaries, with a lag of three months, including appointments with external parties; see, https://www.ecb.europa.eu/ecb/orga/transparency/ calendars-of-the-EB-members/html/index.en.html.
} 
particular when the individual behavior of judges is at stake. Accordingly, the individual accountability of CJEU members is regulated in-house. There have been very few cases, where the behavior of judges or Advocates General has been subject to disciplinary measures. ${ }^{124}$ The rules on deprivation of office of a judge or Advocate General have never been applied in practice. ${ }^{125}$ The occasional lift of immunity has normally been requested by judges themselves. ${ }^{126}$ There has been one case investigated into by the European antifraud office OLAF. ${ }^{127}$ However, these remain individual, rare and scattered instances of individual accountability.

Of greater practical relevance, is the question of institutional accountability. The key mechanism in this regard is the EU's budgetary process, the key player the European Parliament. ${ }^{128}$ Every year, the Court explains its administrative activities in a management report. Based on an assessment by the European Court of Auditors, a recommendation by the Council and a report by the European Parliament's Committee on Budgetary Control, the European Parliament grants discharge to the Registrar of the Court. ${ }^{129}$ The Parliament has developed the practice to request additional information from the CJEU in the form of questionnaires and adds observations to its discharge decisions, commenting on problems and proposing reforms.

While the decision on discharge is first and foremost a political act, without immediate effect for the Court's budget, ${ }^{130}$ Parliament's observations nevertheless carry significant

\footnotetext{
${ }^{124}$ See Hancisse, McMenamin, Perera \& Patz, supra note 78, at 129.

${ }^{125}$ See Article 6 of the Court's Statute.

${ }^{126}$ Between 2004 and 2013 the immunity of a CJEU judge or Advocate General has been lifted ten times, only one included a request by a third party; Hancisse, McMenamin, Perera \& Patz, supra note 78, at 129.

1272012 discharge questionnaire to the European Court of Justice, (on file with the author) at 4; for the competences of OLAF as regards the CJEU and the modalities of their cooperation see, Décision de la Cour du 12 juillet 2011 portant modification de la décision du 26 octobre 1999 relative aux conditions et modalités des enquêtes internes en matière de lutte contre la fraude, la corruption et toute activité illégale préjudiciable aux intérêts des Communautés.

128 In detail, Christoph Krenn, The European Court of Justice's Financial Accountability. How the European Parliament Incites and Monitors Judicial Reform through the Budgetary Process, 13 EUROPEAN CONSTITUTIONAL LAW REVIEW, 253 (2017).

${ }^{129}$ Formally, according to Article 319 TFEU, discharge is granted to the Commission for the implementation of the budget. In practice, however, the European Parliament grants individual discharge to those in charge of implementing the budget within the specific institution. The Registrar is, under the supervision of the ECJ's president, responsible for the implementation of the CJEU's budget.

${ }^{130}$ Diemut Theato, Die Haushaltskontrolle durch das EP und sein Beitrag zur Entwicklung eines europäischen Sanktionsrechts, in EUROPÄISCHE DEMOKRATIE 111 (Josef Drexl ed., 1999). In case of disapproval it does not lead to a budgetary impasse for the Court, see, Siegfried Magiera, Artikel 319 AEUV, in DAS RECHT DER EUROPÄISCHEN UNION, supra note 72 , at margin number 9 .
} 
weight. Article 166 of the EU Financial Regulation foresees the duty to 'take all appropriate steps to act on the observations accompanying the European Parliament's discharge decision [...]. ${ }^{131}$ Moreover, a failure to reply and act upon Parliament's objections will lead to insistent inquiry during the next discharge procedure and can eventually lead to a reduction of appropriations. ${ }^{132}$ Management issues that were addressed by Parliament include invoicing irregularities, ${ }^{133}$ the Court of Justice's expenditure on buildings, ${ }^{134}$ the non-official use of official cars by members of the Court, ${ }^{135}$ gender balance within the Court's administrative departments, ${ }^{136}$ or the frequency of judicial members' visits to academic conferences. ${ }^{137}$

In the course of the budgetary process, the European Parliament does not prescribe the Court en détail how to organize the institution, but it checks for mismanagement and gives political guidance on broader issues of court administration. A constructive dialogue has developed over the past years. The Court is eager to underline that it responds quickly and aptly to the Parliament's proposals. ${ }^{138}$ The Parliament, on the other side, has resisted turning the budgetary process into an assessment of the Court's judicial decisions. Rather, it has shown itself committed to ensuring an adequate financing for the Court. ${ }^{139}$ The Parliament generally acts vis-à-vis the Council as a guardian for the Court's financial well-

${ }^{131}$ Art. 166 para. 1 of the 2012 Financial Regulation (EU, Euratom) No. 966/2012 of the European Parliament and of the Council [2012] OJ L298/1.

${ }^{132}$ As regards the CJEU this was threatened by the Parliament in its 2004 discharge resolution, see [2004] OJ L330/141, point 15, regarding the non-official car use by members of the court and the system of salary weightings.

${ }^{133}$ European Parliament, Discharge decision for the financial year 2000, [2002] OJ L158/66, para. 19.

${ }^{134}$ European Court of Auditors, Special Report no 5/2000, [2000] OJ C109.

${ }^{135}$ European Parliament, Discharge decision for the financial year 2002, [2004] OJ L330/140, paras. 5-15.

${ }^{136}$ European Parliament decision of 18 April 2018 on discharge in respect of the implementation of the general budget of the European Union for the financial year 2016, Section IV - Court of Justice (2017/2139(DEC), para 37.

${ }^{137} 2013$ discharge. Questionnaire to the European Court of Justice, at 10 (on file with the author).

${ }^{138}$ Following up the observations or recommendations in the discharge resolution of the European Parliament of 3 April 2014 for the year 2012. Replies given and steps taken by the Court of Justice. ('The Court has made every effort to act upon [the observations/recommendations expressed by the EP] as soon as possible.').

${ }^{139}$ Already in the early 1980s, in the wake of severe budget cuts, the Parliament blocked attempts by the Council to include the Court among those institutions whose budget should be cut by five percent; see European Parliament, Report drawn up on behalf of the Committee on Budgets on Section IV - Court of Justice - of the draft general budget of the European Communities for the financial year 1983 (25 October 1982) Document 1$781 / 82$. 
being, ${ }^{140}$ while at the same time critically supervising the Court's institutional development. To be sure, not all proposals by the Parliament can unequivocally be supported. ${ }^{141}$ Yet, in principle, the budgetary process has proven a meaningful instrument to ensure that the CJEU is guided and held to account for its administrative governance, while respecting the Court's institutional independence.

\section{E. Conclusion}

The CJEU's particular version of JSG, which has been incrementally developed over the course of the last 65 years, can be associated with a number of positive effects. This has been the central argument of this contribution. The collegial nature of self-government at the Court provides an institutional environment in which conflicts on how to govern the institution can, in principle, be managed internally and successfully. The establishment of the 255 expert panel can be seen to increase confidence in the Court's judges, notably by the Court's key compliance constituencies. Moreover, peer review of CJEU members' conduct while in office, as well as the buffer the Court's press department provides, help to protect judicial independence. At the same time, problematic side effects of JSG, such as a lack of transparency and accountability, have been largely avoided. This is not to say that room for improvement does not exist. Notably, when it comes to more recent developments, such as the influential role of the 255 Panel on judicial appointments or the Court's legislative tasks in amending its own Statute, more transparency would be required.

This contribution has highlighted the legal architecture of administrative governance at the CJEU. It has discussed its many strong and its few problematic features. Yet, ultimately, the success of JSG is dependent on conditions institutional design can only induce, but not guarantee. The most inclusive and collegial governance structure is of little use if collegiality is not lived. The most elaborate rules on financial accountability are meaningless if an accountability relationship is abused. With very few exceptions, ${ }^{142}$ collegiality (internally) and institutional dialogue (externally) have been the background norms of JSG at the CJEU. Whether they can be upheld, will determine whether JSG will also in the future be a bedrock for the CJEU's institutional success.

\footnotetext{
${ }^{140} \mathrm{See}$, for instance, the Court's statement that 'budgetary resources relating to IT functioning and development should be preserved by the budgetary authority, as done thanks to the amendments supported by the European Parliament during last years.' See, Discharge 2011: questions from M. Kalfin (on file with the author), at 4.

${ }^{141}$ For an analysis and critique see, Krenn, supra note 128.

${ }^{142}$ See, for instance, supra notes 50 and 56.
} 